\title{
Phytochemical Analysis and Assessment of Antibacterial and Antioxidant Activities of Phytolacca dodecandra L. Herit Leaf Extracts (Phytolaccaceae)
}

\author{
Jeff Bekomo Iteku ${ }^{1,2, ~ *, ~ O r n e l l a ~ M b a y i ~}{ }^{2}$, Gedeon Ngiala Bongo ${ }^{2}$, Paulin Kapepula Mutwale ${ }^{4}$, \\ Jose Mulwahali Wambale ${ }^{4}$, Emmanuel Lengbiye ${ }^{2}$, Clement Liyongo Inkoto ${ }^{2}$, \\ Samy Ngunde Ngunde $^{1}$, Koto-te-Nyiwa Ngbolua ${ }^{2,3}$ \\ ${ }^{1}$ Higher Pedagogical Institute of Yakoma, Nord-Ubangi City, Democratic Republic of the Congo \\ ${ }^{2}$ Department of Biology, Faculty of Science, University of Kinshasa, Kinshasa City, Democratic Republic of the Congo \\ ${ }^{3}$ Department of Environmental Sciences, University of Gbadolite, Nord-Ubangi City, Democratic Republic of the Congo \\ ${ }^{4}$ Faculty of Pharmaceutical Sciences, University of Kinshasa, Kinshasa City, Democratic Republic of the Congo
}

Email address:

jeffitekubekomo@gmail.com (J. B. Iteku)

${ }^{*}$ Corresponding author

\section{To cite this article:}

Jeff Bekomo Iteku, Ornella Mbayi, Gedeon Ngiala Bongo, Paulin Kapepula Mutwale, Jose Mulwahali Wambale, Emmanuel Lengbiye, Samy Ngunde Ngunde, Koto-te-Nyiwa Ngbolua. Phytochemical Analysis and Assessment of Antibacterial and Antioxidant Activities of Phytolacca dodecandra L. Herit Leaf Extracts (Phytolaccaceae). International Journal of Biomedical Engineering and Clinical Science. Vol. 5, No. 3, 2019, pp. 31-39. doi: 10.11648/j.ijbecs.20190503.11

Received: August 23, 2019; Accepted: September 26, 2019; Published: October 11, 2019

\begin{abstract}
From times immemorial, medicinal plants have been used to relieve and cure human diseases. Currently, the control of bacterial infections is becoming complex due to the concern of antibiotic resistance, which has been a significant global health problem. The aim of this work was to determine the phytochemical composition as well as to assess the bioactivities of Phytolacca dodecandra leaf extracts. The leaves of $P$. dodecandra were collected in January 2017 at Yakoma city, Nord-Ubangi, DRC. Three bacterial strains namely Staphylococcus aureus ATCC 25923, Escherichia coli ATCC 8739 and Pseudomonas aeroginosa ATCC 9027 were used for the assessment of the antibacterial activity. The qualitative and quantitative phytochemical screening were used for compound identification. The antioxidant activity was assessed using ABTS and DPPH scavenging tests while the antibacterial activity was performed using the diffusion method. The findings show that leaves of this plant are rich in flavonoids, anthocyanins, terpenoids and irrioids. The inhibitory concentration 50 $\left(\mathrm{IC}_{50}\right)$ values obtained in the ATBS test are lower than those of the DPPH test. The antibacterial activity of this plant was low against the three strains used. These in vitro findings show that medicinal plants have very important biological properties that have many applications in various fields such as medicine, pharmacy and agriculture.
\end{abstract}

Keywords: Phytolacca dodecandra, Antibiotic Resistance, Bioactivity, Yakoma, DRC

\section{Introduction}

Since ancient times, medicinal plants have been used to relieve and cure human diseases. In fact, their therapeutic properties are due to the presence of hundreds or even thousands of natural bioactive compounds called secondary metabolites. These metabolites are accumulated in different organs and sometimes in specialized cells of the plant [1]. In fact, WHO [2]. estimates that $80 \%$ of the African population still uses traditional medicine to treat themselves, with most therapies involving the use of their active ingredients. These plant species of such great importance for the health of populations deserve to be scientifically studied for their best use 3. More than $25 \%$ of drugs prescribed in developed countries are derived directly or indirectly from plants. However, as sources of medicines, plants are still underexploited, especially in the field of medical microbiology [4]. Oxygenated Reactive Species (ORS) are involved in 
physiological processes in small quantities. However, the excess production of ORS can become toxic to the major components of the cell and gives rise to oxidative stress, which will be involved in various pathologies such as neurodegenerative diseases (Alzheimer, Parkinson), diabetes, cancer, inflammatory diseases, aging, etc. Cells use many antioxidant strategies to eliminate or minimize the oxidative damage.

Currently, the control of bacterial infections is becoming complex due to the antibiotic concern, which is for the moment a significant global health problem. However, there is a concern about the adverse effects of synthetic molecules intended to combat oxidative stress and bacterial infections. It therefore seems important to find an alternative to the use of synthetic antioxidants and conventional antibiotics. Herbal remedies are an alternative in primary care systems and therefore a promising avenue for the development of traditionally improved medicines [5]. Recently, many researchers have been interested in medicinal plants for their richness in natural antioxidants such as polyphenols, flavonoids, tannins, etc. that have antioxidant and antimicrobial activities. As a result, the exploitation of new bioactive molecules with limited or no side effects from natural sources and their adoption as a therapeutic alternative to synthetic molecules have become prior objectives for scientific research as well as the food and pharmaceutical industries [5]. Flavonoids have been particularly studied because of their use in pharmaceuticals, cosmetics and food for their health benefits. Flavonoids are mainly known for their antioxidant action, modulating the activity of certain enzymes, vaso-protective, anti-inflammatory and antidiabetic. The increased interest of naturally occurring antioxidants to increase food preservation is explained by the fact that some synthetic antioxidants are at risk of carcinogenicity [6].

In order to scientifically validate the traditional use of medicinal plants in the Democratic Republic of the Congo (DRC), we chose Phytolacca dodecandra. This plant is used in African traditional medicine against skin diseases such as ringworm, scabies, leprosy, boils and treats intestinal problems such as abdominal pain [7-8]. The aim of the current research was to determine the phytochemical composition and evaluate the bioactivities of $P$. dodecandra leaf extracts. The specific objectives were: (i) to perform micrographic analysis of $P$. dodecandra powders; (ii) to determine the qualitative phytochemical composition and the content of total polyphenols, flavonoids and anthocyanins in $P$. dodecandra leaves. (iii) to evaluate of the antioxidant activity of leaf extracts using DPPH and ABTS tests, and (iv) to evaluate the antibacterial activity of leaf extracts against three microbial strains.

\section{Material and Methods}

\subsection{Materials}

\subsubsection{Plant Material}

The leaves of $P$. dodecandra were used as plant material.
These leaves were collected in Yakoma city, Nord-Ubangi, DRC in January 2017. This plant has been identified at the Herbarium of the Institut National d'Etudes et de Recherches Agronomiques located at the Faculty of Sciences, University of Kinshasa. Later, this plant material was dried at the laboratory temperature for two weeks and pulverized in the mill to obtain fine powder.

\subsubsection{Bacterial Strains}

The bacterial strains used for the assessment of the antibacterial activity were provided by the Laboratory of Microbiology, Faculty of Pharmaceutical Sciences, University of Kinshasa. These strains were namely: Staphylococcus aureus ATCC 25923, Escherichia coli ATCC 8739 and Pseudomonas aeroginosa ATCC 9027.

\subsection{Methods}

\subsubsection{Microscopic Feature (Powder Micrography)}

This experiment was performed according to Inkoto et al. [9]. Microscopic features or powder micrography is one of the most fundamental methods of controlling plant drug quality. It is very important to carry out well the preparation of the plate to be observed under the microscope in order to distinguish different elements constituting the powder. Twothree drops of selected reagent (Steimetz reagent) were placed on a slide and a small amount of powder is added. This slide is covered with a cover-slide in order to homogenize the preparation followed by the microscopic feature examination. Observations were made with a Hund WETZLAR microscope, and pictures were taken with Digital Camera CANON IXUS 165.

\subsubsection{Qualitative Phytochemical Screening}

Phytochemical screening represents all the qualitative techniques used to determine or identify the different chemical groups (secondary metabolites) contained in an extract. These chemical groups constitute the active ingredients and are identified by means of coloring and precipitation reactions that take place by adding specific reagents [10-12]. This test can be performed on aqueous extracts for water-soluble substances or on organic extracts for fat-soluble principles. The aqueous extracts were obtained by macerating $5 \mathrm{~g}$ of the powder in $100 \mathrm{~mL}$ of distilled water during 24 hours in the laboratory temperature, then filtered using filter paper (Whatman $n^{\circ} 1$ ). While for the organic extract, the maceration of two grams was performed with 70 $\mathrm{mL}$ of methanol for 48 hours then filtered using a filter paper (Whatman $n^{\circ} 1$ ).

\subsubsection{Quantitative Phytochemical Screening Using TLC}

This screening was performed following the standard protocol as described by Inkoto et al. [9], Tiwari et al. [13] and Bahati et al. [14].

\section{i. Determination of flavonoids and phenolic acids}

One gram of pulverized drug was extracted with $5 \mathrm{~mL}$ of methanol by stirring for 10 minutes. Afterwards, $10 \mathrm{~mL}$ of filtrate used for Thin Layer Chromatography (TLC) analysis for the determination of different compounds. Silica gel F254 
was used as a stationary phase, and ethyl acetate - formic glacial acetic acid -water (100:11:11:26) as mobile phase 1, dichloromethane - formic acid - acetone (80:10:20) as mobile phase 2 and ethyl acetate - methanol - water (100:13.5:10) as mobile phase 3. As controls, Rutin, hyperoside, isoquercitrin and chlorogenic acid were used. Once developed, the chromatogram was observed under UV at 254 and $366 \mathrm{~nm}$ and was then sprayed with the Neu reagent and observed under UV at $366 \mathrm{~nm}$. The presence of flavonoids was marked by the presence of fluorescent spots of various colors (yellow-orange-green) varying according to the structure of highlighted compounds and phenolic acids were observed as blue fluorescent spots.

\section{ii. Determination of Iridoids}

As for flavonoids, Silicagel F254 remained the stationary phase and ethyl acetate - methanol - water (100:13.5:10) were used as mobile phase. The revelation was carried out with sulfuric acid 5\% in ethanol by heating for 10 minutes at $100^{\circ} \mathrm{C}$. True iridoids gave colorations, while other terpenes were colored in black.

\section{iii. Determination of Anthocyanins}

For Anthocyanins test, stationary phase remained same as described above and ethyl acetate - formic acid - water (100:10:40) was considered as the mobile phase. The revelation was performed with phosphoric vanillin on the plate by heating for 10 minutes at $100^{\circ} \mathrm{C}$. The pink coloration shows the presence of anthocyanins.

\section{iv. Determination of Anthraquinones (anthracene heteroglycosides)}

The ethyl acetate-methanol-water (100:13.5:10) was used as mobile phase. The revelation was performed under UV between 254 and $366 \mathrm{~nm}$ and the spraying was performed with ethanolic $\mathrm{KOH}(10 \%)$. The anthraquinones were red colored reflecting red fluorescence at $366 \mathrm{~nm}$, while anthrones were colored in yellow.

\section{v. Determination of Terpenes}

One gram of pulverized drug was extracted with $10 \mathrm{~mL}$ of dichloromethane by stirring for 15 minutes. The filtrate was evaporated to dryness and the residue was dissolved in $0.5 \mathrm{~mL}$ of toluene. Silicagel F254 was used as stationary phase and ethyl toluene-acetate (93:7) was used as mobile phase. Thymol, menthol, oleanic acid and $1 \mathrm{mg} / \mathrm{mL}$ (methanol) were used as standards. The revelation was performed with sulfuric vanillin by heating for 10 minutes at $100^{\circ} \mathrm{C}$. Terpenes gave various colors using this reagent.

vi. Determination of Coumarins

The mobile phase used was toluene-ether (1:1, saturated with $10 \%$ acetic acid). This mobile phase was prepared from the mixture of $10 \mathrm{~mL}$ of toluene, $10 \mathrm{~mL}$ of ether and $10 \mathrm{~mL}$ of $10 \%$ acetic acid in a separatory funnel, where lower phase was removed and the upper phase was used as mobile phase. The revelation was performed under UV between 254 and $366 \mathrm{~nm}$ and the spraying was done with ethanolic $\mathrm{KOH}$ $(10 \%)$. The blue color was charasterisitic of coumarins. vii. Determination of Alkaloids

In an acidic medium, $0.3 \mathrm{~g}$ of drug powder was introduced into an Erlenmeyer flask and $3 \mathrm{~mL}$ of diluted hydrochloric acid 5\% were added. The mixture was sealed and stirred for 30 minutes and the filtrate was collected. In a test tube, five drops of Mayer's reagent was added to one $\mathrm{mL}$ of the filtrate. The presence of alkaloids was observed by the appearance of a white precipitate. In case, where this general test was positive, a thin layer chromatography (TLC) was required. One gram of the drug powder was macerated into one $\mathrm{mL}$ of ammonia $10 \%$ in an Erlenmeyer flask; $5 \mathrm{~mL}$ of ethyl acetate (or methanol to extract the quaternaries) was added and stirred for 30 minutes. Further, $20 \mu \mathrm{L}$ and 50 $\mu \mathrm{L}$ of filtrate were used for TLC analysis. Dichloromethane - methanol - ammonia 25\% (8:2:0.5) served as a mobile phase and $5 \mathrm{mg} / \mathrm{mL}$ caffeine was used as control. The chromatogram was observed under UV between 254 and $366 \mathrm{~nm}$ and was then sprayed using. Draggendorff reagent and observed under the visible light. The presence of alkaloids was marked by the presence of spots ranging from yellow-orange to yellow-brown.

\subsubsection{Secondary Metabolite Contents}

\section{i. Total polyphenol content}

Total polyphenol content of extracts was determined using the Folin-Ciocalteu method [10]. Ten $\mathrm{mg} / \mathrm{mL}$ of each extract was diluted in methanol $80 \%$ in order to obtain a $1 \mathrm{mg} / \mathrm{mL}$ solution for each extract. Afterwards, for each extract, a reaction mixture composed of $0.5 \mathrm{~mL}$ of extract, $5.0 \mathrm{~mL}$ of distilled water and $0.5 \mathrm{~mL}$ of Folin-Ciocalteu reagent was prepared. Three minutes later, $1.0 \mathrm{~mL}$ of saturated $\mathrm{Na}_{2} \mathrm{CO}_{3}$ $20 \%$ solution was added to the mixture. Different mixtures prepared were stirred and incubated at the laboratory temperature under shade for one hour. The absorbance was read at $725 \mathrm{~nm}$ and the analysis was performed in triplicate. The amount of total polyphenols was expressed in $\mathrm{mg}$ equivalents of gallic acid (GAE)/g of dry extract using the following equation from the calibration line:

$$
\mathrm{y}=1.7097 \ln (\mathrm{x})+5.2062 \text { and } \mathrm{R}^{2}=0.965
$$

where $\mathrm{x}$ is the absorbance and $\mathrm{y}$ is the equivalent of gallic acid (mg/g).

\section{ii. Total flavonoid content}

The reaction mixture contained one $\mathrm{mL}$ of methanol solution $(80 \%)$ of each of extracts having a concentration of ten $\mathrm{mg} / \mathrm{mL}$ and one $\mathrm{mL}$ of $\mathrm{AlCl}_{3} 2 \%$ (dissolved in methanol) and the whole mixture was well stirred. After one hour of incubation at the laboratory temperature and under shade, different absorbances were measured at $415 \mathrm{~nm}$ using a spectrophotometer (GENESYS 10S). For each analysis, mixtures were prepared in duplicate. For preparing the blank, the procedure was the same as described above but in lieu of the extract, one $\mathrm{mL}$ of methanol was added. The flavonoid content of the extracts was expressed in $\mathrm{mg}$ equivalent quercetin $(\mathrm{QE}) / \mathrm{g}$ of corresponding dry extract using the equation from the calibration line:

$$
\mathrm{y}=0.5001 \ln (\mathrm{x})+3.442, \text { and } \mathrm{R}^{2}=0.944
$$

where $\mathrm{x}$ is the absorbance and $\mathrm{y}$ is the equivalent of quercetin $(\mathrm{mg} / \mathrm{g})[15]$. 


\section{iii. Anthocyanin content}

The determination of the anthocyanin content of extracts is carried out by the procedure reported by Adedapo et al. [16]. We sampled $0.5 \mathrm{~mL}$ of the $1 \mathrm{mg} / \mathrm{ml}$ solution of $1 \mathrm{mg} / \mathrm{ml}$ extract prepared in methanol $80 \%$, which was mixed with 3 $\mathrm{mL}$ of vanillin methanol solution $(4 \%)$ and $1.5 \mathrm{~mL}$ of hydrochloric acid. Then, the mixture was incubated for an hour and the absorbance was measured at $500 \mathrm{~nm}$. Mixtures were prepared in triplicate, and the average value was used. The same procedure was repeated for the reference substance (D-catechin) in the concentration range of $4 \mathrm{mg} / \mathrm{mL}$ to 0.125 $\mathrm{mg} / \mathrm{mL}$ and allowed the calibration line to be established. The anthocyanin content of the extracts is expressed in $\mathrm{mg}$ equivalent $\mathrm{D}$-catechin per $\mathrm{g}$ of corresponding dry vegetable matter $(\mathrm{EC} / \mathrm{g})$ using the following equation from the calibration line:

$$
\mathrm{y}=0.0286 \mathrm{x}+0.0508 \text { and } \mathrm{R}^{2}=0.988
$$

where $\mathrm{x}$ is the absorbance and $\mathrm{y}$ is the catechin equivalent (mg/g).

\subsubsection{Assessment of Biological Activities}

\section{$i$. Preparation of samples}

Ten mg of dry extract of each sample were dissolved in 1 $\mathrm{mL}$ of methanol for polar extracts and the mixture of dichloromethane-methanol (1:1) for apolar extracts (solution A: $10 \mathrm{mg} / \mathrm{mL}$ ). The dilution was carried out with different concentrations as follows: $8 \mathrm{mg} / \mathrm{mL}, 6 \mathrm{mg} / \mathrm{mL}, 4 \mathrm{mg} / \mathrm{mL}$ and $2 \mathrm{mg} / \mathrm{mL}$. The assessment of biological activities was performed according to Bongo et al. [17].

\subsubsection{Evaluation of Antioxidant Activity}

The antioxidant activity was assessed according to Kapepula et al. [15] and Sochor et al. [18].

\section{i. ABTS Radical Scavenging Capacity}

In reaction with potassium or sodium persulfate $\left(\mathrm{K}_{2} \mathrm{~S}_{2} \mathrm{O}_{8}\right)$, the ABTS (2,2'-azino-bis-3-ethylbenz-thiazoline-6-sulfonic acid) forms the cationic radical ABTS from blue to green color. The addition of antioxidant reduces this radical and causes the mixture decolorization. The decolorization of the radical measured by spectrophotometry at $734 \mathrm{~nm}$ is proportional to the concentration of antioxidants.

Dissolve in $500 \mu \mathrm{L}$ of distilled water a quantity of ABTS reagent corresponding to 20 millimoles: solution A. Then dissolve in $500 \mu \mathrm{L}$ of distilled water a quantity of potassium persulphate $\left(\mathrm{K}_{2} \mathrm{~S}_{2} \mathrm{O}_{8}\right)$ corresponding to 10 millimoles: solution B. Therefore, mix both solutions $\mathrm{A}$ and $\mathrm{B}$ at equal volume and keep the mixture away from light between 12 and 16 hours: this solution constitutes the stock solution for

ABTS radical. Then dilute the stock solution of the radical with methanol $\mathrm{x}$ times in order to obtain an analytical solution of which the absorbance ranges between 0.800 and 1.000. In a test tube, place $20 \mu \mathrm{L}$ of methanol with $1980 \mu \mathrm{L}$ of solution of ABTS: control solution. On the other hand, in another test tube, place $20 \mu \mathrm{L}$ of the sample solution for each concentration level, and add to this solution $1980 \mu \mathrm{L}$ of ABTS radical working solution and incubate for 30 minutes in the absence of light. Successive reading of solutions for each concentration level is performed at $734 \mathrm{~nm}$ with the spectrophotometer: blank (methanol), control solution and samples.

The percentage inhibition of ABTS radical is determined as follows:

$$
\% \text { inhibition }=\left[1-\frac{A_{x}}{A_{c}}\right] \times 100
$$

Where, Ax: the absorbance of ABTS radical in the presence of the extract.

Ac: absorbance of ABTS (control solution).

The ABTS scavenging activity of extracts was expressed in $\mathrm{IC}_{50}$. Different $\mathrm{IC}_{50}$ values were determined using Graph Pad Prism version 6.0 software. The experiment was performed in triplicate.

\section{ii. DPPH Radical Scavenging Capacity}

This method is based on the degradation of DPPH radical (2,2 DiPhenyl-1-PicrylHydrazyl). The DPPH radical is a violet-colored radical, the addition of antioxidant reduces this radical and causes the mixture to discolor. This radical decolorization measured by spectrophotometer at $517 \mathrm{~nm}$ is proportional to the concentration of antioxidants.

Dissolve $3.2 \mathrm{mg}$ of DPPH in $100 \mathrm{~mL}$ of methanol $(80 \%)$ and this solution is kept out in the dark for at least an hour. The absorbance of this solution must be adjusted to $0.7 \pm 0.05$ using methanol (80\%). So, in a test tube, mix $20 \mu \mathrm{L}$ of methanol with $1980 \mu \mathrm{L}$ of DPPH radical solution: control solution. In another test tube, place $20 \mu \mathrm{L}$ of sample for each concentration by adding to $1980 \mu \mathrm{L}$ solution of DPPH radical working solution and incubate for 30 minutes in the absence of light. Successive reading of the solutions for each concentration is carried out using a spectrophotometer at 517 $\mathrm{nm}$ : blank (methanol), control solution and different sample solutions. The DPPH radical inhibition percentage for each sample was determined using the following formula:

$$
\% \text { inhibition }=\left[1-\frac{A x}{A c}\right] \times 100
$$

Where, Ax: the absorbance of DPPH radical in the presence of the extract.

Ac: absorbance of DPPH (control solution).

DPPH scavenging activity of extracts was expressed in $\mathrm{IC}_{50}$. Different $\mathrm{IC}_{50}$ values were determined using Graph Pad Prism version 6.0 software. Each sample was measured in triplicate.

\subsubsection{Evaluation of the Antibacterial Activity}

The antibacterial activity was evaluated using the microdilution method in liquid medium as previously reported [1920]. The extract to be tested $(20 \mathrm{mg})$ was dissolved in $250 \mu \mathrm{L}$ of DMSO and the final volume was adjusted to $5 \mathrm{~mL}$ with Mueller Hinton culture medium (final concentration in DMSO equals to $5 \%$ ). The bacterial suspension was prepared by adding in $2 \mathrm{~mL}$ of saline solution for each strain, three colonies isolated from strains to be tested (Staphylococcus aureus ATCC 25923, Escherichia coli ATCC 8739 and Pseudomonas aeroginosa ATCC 9027) and a-24h incubation 
allowed to obtain $0.5 \mathrm{McF}$ arland $\left(10^{8}\right.$ cells $\left./ \mathrm{mL}\right)$. Therefore, the bacterial suspension was diluted in order to have $10^{6}$ cells/mL (1:100 dilution). Various bacterial suspensions were cultured in Petri dishes containing Mueller Hinton medium using the swabbing technique. Using a pasteur pipette, wells were dug in Mueller Hinton agar poured into the petri dish. Then, $100 \mu \mathrm{L}$ of different concentrations for each extract were distributed in each well. The positive control was placed in another well. After diffusion, the cultures were incubated in the oven at $37^{\circ} \mathrm{C}$ for 24 hours, and the inhibition rings were measured around each well.

\section{Results and Discussion}

\subsection{Botanical Microscopic Characters}

The microscopic examination of $P$. dodecandra leaf powder, is shown in the figure below.

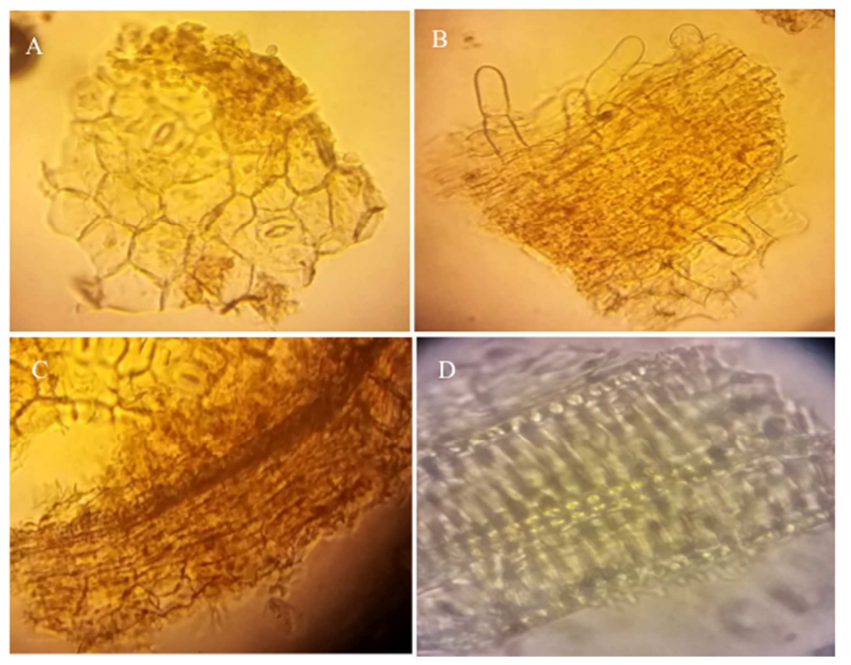

Figure 1. Micrographic characteristics of $P$. dodecandra: polyhedral epidermal cells with polycitic stomata (A), multicellular glandular hairs (B), urchin-shaped calcium oxalate crystals $(C)$, spiral vessel fragments $(D)$.

As observed, the microscopic analysis of $P$. dodecandra leaf revealed the presence of the following histological elements: polyhedral epidermal cells, multicellular glandular hairs, urchin-shaped calcium oxalate crystals and spiral vessel fragments. This analysis allowed highlighting specific histological characteristics of this species and these characteristics allow to determine the originality of the plant.

To the best of our knowledge, no information has been reported on the micrographic study of $P$. dodecandra. In view of their use in traditional medicine, it is important to promote this plant while carrying out the standardization, for which the determination of histological elements of drugs for the elaboration of monographs, prove to be paramount for the detection of falsifications.

\subsection{Yield of Extraction}

The extraction yield of leaf powder from $P$. dodecandra is presented in the table below.
Table 1. Yield of extraction.

\begin{tabular}{ll}
\hline Extracts & Yield (\%) \\
\hline n-hexane & $6.9 \%$ \\
Dichloromethane & $1.5 \%$ \\
Methanol & $11 \%$ \\
Water & $12.1 \%$ \\
\hline
\end{tabular}

From the above table, it is observed that the aqueous extract has the highest yield compared to other extracts. It is followed by methanol, n-hexane and dichloromethane extracts, which presented a certain yield, but the dichloromethane extract presented a lower yield (1.5\%).

\subsection{Secondary Metabolites}

\section{Qualitative Phytochemical Screening}

The phytochemical screening (using precipitation reactions) performed on aqueous and organic extracts of $P$. dodecandra is presented in table 2 .

Table 2. Phytochemical screening of P. dodecandra using precipitation reactions.

\begin{tabular}{|c|c|}
\hline Researched compounds & Findings \\
\hline Polyphenols & + \\
\hline Flavonoids & + \\
\hline Tannins & + \\
\hline Bound quinones & - \\
\hline Saponines & + \\
\hline Alkaloid & + \\
\hline Leuco-anthocyanins & + \\
\hline Anthocyanins & + \\
\hline Steroids et triterpenoids & + \\
\hline
\end{tabular}

From the above table, it is reported the presence of various secondary metabolites namely polyphenols, tannins, saponins, alkaloids, leuco-anthocyanins, anthocynins and steroids \& triterpenoids. Mekonnen reported the same profile of metabolites for this species precisely the presence of alkaloids, saponins and phenolic compounds [21]. Studies have shown that the presence of secondary metabolites such as alkaloids, anthocyanins, flavonoids, polyphenols, saponins, tannins, steroids and triterpenes in plants confer the antibacterial activity to plants [22-23].

\subsection{TLC Profiles of Different Compounds}

\subsubsection{Flavonoids and Phenolic Acids}

The findings of the TLC analysis revealed the presence of specific secondary metabolites including phenolic compounds in the leaves of $P$. dodecandra (figures 2 and 3 ).

The analysis of the chromatographic systems II and III (Figures 2 and 3) reveals the presence of flavonoids and phenolic acids corresponding to fluorescent spots of yelloworange-green colours for flavonoids and blue fluorescents for phenol acids. The different systems have allowed us to identify more polar compounds that are heterosides such as rutin, quercitrine and less polar compounds such as quercetin and kaempferol. In comparison with the standards used (controls), we consider that the extract of $P$. dodecandra does 
not contain these compounds. However, it contains more phenolic acids than flavonoids. Flavonoids are kaempferoltype compounds that would be in the majority (green spots: Figure 3).

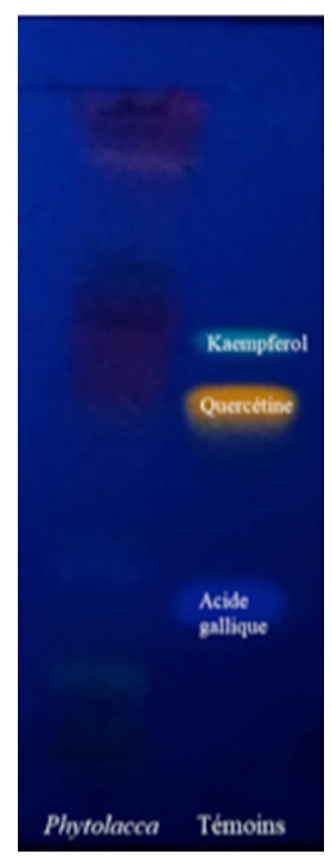

Figure 2. TLC Chromatogram of methanol extracts of P. dodecandra with control at $366 n \mathrm{~m}$.

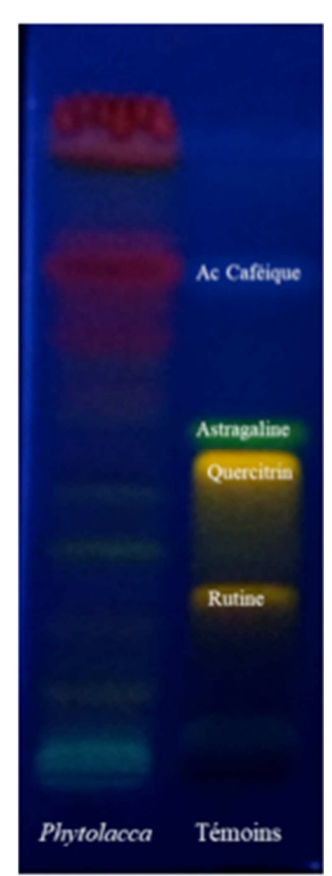

Figure 3. TLC Chromatogram of methanol extracts of $P$. dodecandra with control at $366 \mathrm{~nm}$.

\subsubsection{Anthocyanins}

The analysis of the chromatogram below (Figure 4) reveals the presence of anthocyanins in the leaves of $P$. dodecandra, though its nature needs to be determined. These anthocyanins correspond to different spots colored in pink on the chromatographic profile. In relation to the control, we note the absence of D-catechin in P. dodecandra.

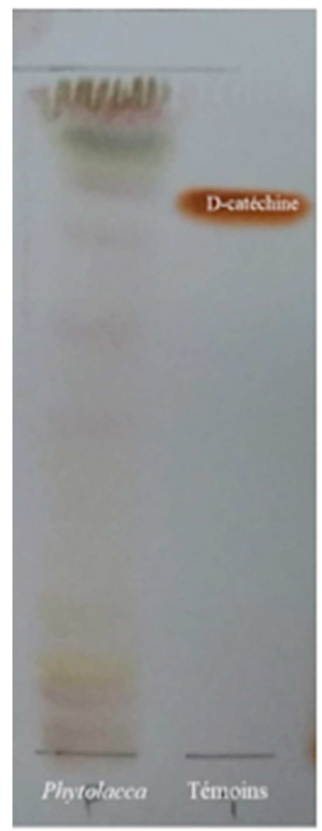

Figure 4. TLC Chromatogram of methanol extracts of P. dodecandra in presence of a control in the visible.

\subsubsection{Terpenoids}

The analysis of Figure 5 confirms the presence of terpenoids corresponding to spots of various colors. Compared to the controls, we estimate that menthol and oleic acid would be present in the leaves of $P$. dodecandra.

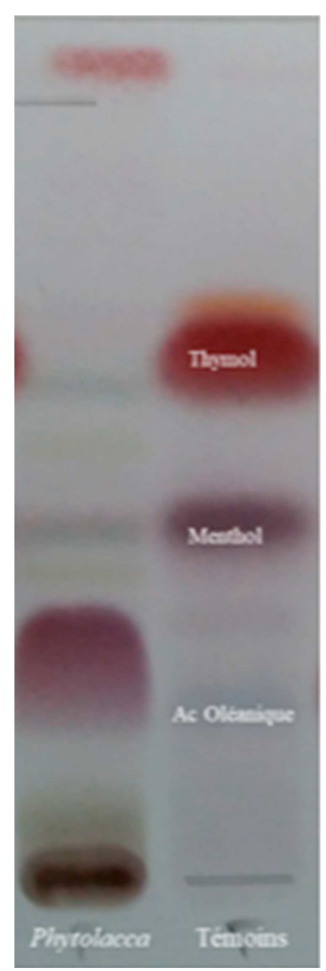

Figure 5. TLC Chromatogram of methanol extracts of $P$. dodecandra in presence of a control in the visible.

In the literature, few studies have reported on the 
phytochemical composition of $P$. dodecandra leaves but the chemical composition of other parts of the plant has been reported. However, Mekonnen [21] reported the presence of phenolic compounds in $P$. dodecandra. Terpenoids: resulting from the condensation of isoprene units, terpenoids with antioxidant activity mainly include monoterpenes, sesquiterpenes, diterpenes and tetraterpenes (Carotenoids) [24]. It is known that carotenoids are natural pigments that protect plants against photo-oxidative processes and they are natural fat-soluble antioxidants. Furthermore, Matebie et al. [25] reported the chemical composition of essential oils of this plant, while Tura et al. [26] reported the presence of saponins, tannins and flavonoids in the fruit of this plant, of which the author used to assess the antibacterial activity.
Using three different solvents namely acetone, petroleum ether and water, Vithya et al. [27], reported the presence of alkaloids, tannins, flavonoids, amino acids, phenols, steroids, terpenoids, saponins and glycosides in the leaves of $P$. octandra. However, carbohydrates were found only with the aqueous extract meanwhile amino acids, steroids, terpenoids and saponins were absent in the aqueous extract. Also, tannins were absent with the petroleum ether extract.

\subsection{Content of Secondary Metabolites}

The content of different secondary metabolites is presented in the table below.

Table 3. Determination of total polyphenols, flavonoids and anthocyanins content.

\begin{tabular}{llll}
\hline Sample & Content in total polyphenols (EAG) & Content in flavonoids (EQ) & Content in anthocyanins (EC) \\
\hline$P$. dodecandra & $4.1 \pm 0.1$ & $0.032 \pm 0.0001$ & $0.067 \pm 0.009$ \\
\hline
\end{tabular}

Legend: EAG: Gallic acid equivalent; EQ: Quercetin equivalent; EC: Catechin equivalent.

From the table, it is observed that phenolic compound levels are relatively low in $P$. dodecandra leaves, with a content of $0.067 \mathrm{mg} / \mathrm{g}$ for anthocyanins while $4.1 \mathrm{mg} / \mathrm{g}$ for total polyphenols and a flavonoid content of $0.32 \mathrm{mg} / \mathrm{g}$.

\subsection{Antioxidant Activity}

The antioxidant activity assessment is presented in the following table.

Table 4. IC $C_{50}$ values $(\mu \mathrm{g} / \mathrm{mL})$ of fractions and of gallic acid for ABTS and DPPH tests.

\begin{tabular}{lll}
\hline Sample extract & ABTS $(\boldsymbol{\mu g} / \mathbf{m L})$ & DPPH $(\boldsymbol{\mu g} / \mathbf{m L})$ \\
\hline n-hexane & $196.72 \pm 62.01$ & ND \\
Dichloromethane & $141.58 \pm 64.48$ & $164.44 \pm 26.55$ \\
Methanol & $38.37 \pm 7.98$ & $62.23 \pm 12.59$ \\
Water & $63.39 \pm 5.95$ & $106.41 \pm 5.53$ \\
Gallic Acid & 0.10 & \\
\hline
\end{tabular}

Legend: ND: not determined i.e. no activity in the range of used concentration.

All extract fractions showed $\mathrm{IC}_{50}$ values $<200 \mu \mathrm{g} / \mathrm{mL}$ in both tests; the methanol and aqueous fractions are the most active, while the antiradical scavenging capacity of other fractions is lower. The $\mathrm{IC}_{50}$ values demonstrate their ability to inhibit radicals that vary significantly in each type of test. This difference in activity can be explained by different chemical composition (qualitative and quantitative) of each fraction in terms of secondary metabolites. The $\mathrm{IC}_{50}$ values obtained in the ATBS test are lower than those of the DPPH test. This difference in activity is attributed to the reaction mechanisms involved in each test. Indeed, the ABTS radical reacts with hydrophilic and lipophilic compounds while the DPPH radical reacts only with hydrophilic compounds [2829]. The antiradical activity is an indicator of the antioxidant activity.

Polyphenols are the most common secondary metabolites in the plant kingdom and they are found from roots to fruits. They have several biological properties including antioxidant capacities for which they are indicated in the management of several diseases. Phenolic compounds are one of the most important groups found in plants, they exert several biological effects as antioxidants, anti-inflammatory, etc. [3032]. Nowadays, the properties of polyphenols are widely studied in the medical field where they are known to have antibacterial, antiviral, anti-tumor, anti-inflammatory, antiallergic and other activities. They also have beneficial effects in the preventive management of cardiovascular and neurodegenerative diseases, obesity and diabetes [33].

\subsection{Antibacterial Activity}

The antibacterial activity of different extracts of $P$. dodecandra is presented in table 5 below.

Table 5. Antibacterial activity of different extracts of P. dodecandra.

\begin{tabular}{|c|c|c|c|c|c|c|c|}
\hline \multirow{2}{*}{ Extracts } & \multicolumn{6}{|c|}{ Concentration $(\mu \mathrm{g} / \mathrm{mL})$} & \multirow{2}{*}{$\mathrm{CMI}(\mu \mathrm{g} / \mathrm{mL})$} \\
\hline & 2000 & 1000 & 500 & 250 & 125 & 62,5 & \\
\hline \multicolumn{8}{|c|}{ Escherichia coli ATCC 25922} \\
\hline n-hexane & - & - & - & - & - & - & 2000 \\
\hline Dichloromethane & - & - & - & - & - & - & 2000 \\
\hline Methanol & - & - & - & - & - & - & 2000 \\
\hline Aqueous Extract & + & + & + & + & - & - & 250 \\
\hline \multicolumn{8}{|c|}{ Staphylococcus aureus ATCC 25923} \\
\hline n-hexane & - & - & - & - & - & - & 2000 \\
\hline Dichloromethane & + & - & - & - & - & - & 2000 \\
\hline
\end{tabular}




\begin{tabular}{|c|c|c|c|c|c|c|c|}
\hline \multirow{2}{*}{ Extracts } & \multicolumn{6}{|c|}{ Concentration $(\mu \mathrm{g} / \mathrm{mL})$} & \multirow{2}{*}{$\mathrm{CMI}(\mu \mathrm{g} / \mathrm{mL})$} \\
\hline & 2000 & 1000 & 500 & 250 & 125 & 62,5 & \\
\hline Methanol & - & - & - & - & - & - & 2000 \\
\hline Aqueous extract & - & - & - & - & - & - & 2000 \\
\hline \multicolumn{8}{|c|}{ Pseudomonas aeruginosa ATCC 9027} \\
\hline n-hexane & - & - & - & - & - & - & 2000 \\
\hline Dichloromethane & + & + & + & - & - & - & 500 \\
\hline Methanol & - & - & - & - & - & - & 2000 \\
\hline Aqueous extract & + & + & - & - & - & - & 1000 \\
\hline
\end{tabular}

From the above table, it is observed that that extracts of $P$. dodecandra have low antibacterial activity against these three bacterial strains, namely E. coli ATCC 25922, $S$. aureus ATCC 25923 and P. aeruginosa ATCC9027. These results are similar to those obtained by Taye et al. [34] who also reported a low bacterial activity of $P$. dodecandra; only the methanol extract is active against $P$. aeruginosa. Tadeg et al. [35] studied the antibacterial activity of the methanol extract of $P$. dodecandra, they used several strains including $S$. aureus, E. coli, $P$. aeruginosa; the results obtained showed that the methanol extract of $P$. dodecandra has a low activity on all three bacterial strains.

\section{Conclusion}

The aim was to evaluate antioxidant and antimicrobial activities of different extracts of $P$. dodecandra. The findings show that this species has specific histological elements and it contains numerous secondary metabolites like polyphenols, anthocyanins, tannins, saponins, alkaloids, steroids, terpenoids and leuco-anthocyans. The determination of total polyphenols, flavonoids and anthocyanins in $P$. dodecandra revealed a low content of phenolic compounds. The methanol fraction and aqueous extract have shown a high antioxidant activity while the $\mathrm{IC}_{50}$ values obtained from the ABTS test are lower than those of the DPPH test. For the antibacterial activity, it was observed that only the dichloromethane and aqueous extracts showed relatively a low activity while other extracts did not exhibit any antibacterial activity. At last, all these in vitro results show that medicinal plants have very important biological properties that have many applications in various fields such as medicine, pharmacy and agriculture.

In terms of perspective, it would therefore be interesting to isolate and characterize the active compounds in different extracts in order to identify molecules responsible of these biological activities in this plant. An in vivo study would also be desirable, to obtain a more in-depth view of the antioxidant and antimicrobial activities of the extracts with respect to other bacterial strains.

\section{References}

[1] Mourad B. (2011). Etude de l'activité antioxydante et antimicrobienne d'extraits d'Artemisia campestris L. Mémoire pour l'obtention du diplôme de Magister, Université Ferhat Abbes-Setif.
[2] WHO (World Health Organization) (2002). Rapport sur la médecine traditionnelle: besoins et potentiels, $\mathrm{N}^{\circ} 4,6 \mathrm{pp}$.

[3] Biyiti L. F., Meko'o DJ. L, Tamzc v., Amvam Zollo P. H. (2004). Recherche de l'Activité Antibactérienne de Quatre Plantes Médicinales Camerounaises. Mémoire de licence Biochimie. Université de Yaoundé 1.

[4] Karou D., Mamoudou H. Dicko, Jacques Simporé, Yameogo S., Souleymane Sanon, Alfred S. Traoré. (2005). Activités antioxydantes et antibactériennes des polyphénols extraits de plantes médicinales de la pharmacopée traditionnelle du Burkina Faso. 4 p.

[5] Benbrinis S. (2012). Evaluation des activités antioxydante et antibactérienne des extraits de Santolina chamaecyparissus. Mémoire pour l'obtention du Diplôme de Magister en biochimie. Universite Ferhat Abbas-Setif/Algerie.

[6] Boutlelis DA (2014). Etude phytochimique et activité antimicrobienne, antioxydante, antihépatotoxique du Marrube blanc ou Marrubium vulgare L. Thèse en vue de l'obtention du diplôme de doctorat en science. Universite Badji Mokhtar - Annaba/Algerie.

[7] Dupuis B (2010). Plantes utiles en Afrique. Mémoire de licence Médecin Kjell B.

[8] Esser KB, Semagn K and Wolde-Yohannes L. (2003). Medicinal use and social status of the soap berry endod (Phytolacca dodecandra) in Ethiopia. Journal of Ethnopharmacology, 85 (2-3): 269-277.

[9] Inkoto CL, Bongo GN, Mutwale PK, Masengo CA, Gbolo B Z, Tshiama C, Ngombe NK, Iteku JB, Mbemba TF, Mpiana PT and Ngbolua KN (2018). Microscopic features and chromatographic fingerprints of selected Congolese medicinal plants: Aframomum alboviolaceum (Ridley) K. Schum, Annona senegalensis Pers. and Mondia whitei (Hook. f.) Skeels. Emergent Life Sciences Research, 4 (1): 1-10.

[10] Sofowora A (1993), Medicinal plant and traditional medicine in Africa, Spectrum Books Ltd, Ibadan, Nigeria, p. 270-289.

[11] Harbone JB. Methods of extraction and isolation 'Phytochemical Methods. $3^{\text {rd }}$ Edition Chapman and Hall, London. 1998; 60-66.

[12] Mbadiko CM, Bongo GN, Mindele LU, Ngbolua KN, Mpiana PT, Ngombe NK, Mutwale PK and Mbemba TF (2019). Effect of drying on the composition of secondary metabolites in extracts from floral parts of Curcuma longa L. Asian Journal of Research in Botany, 2 (2): 1-6.

[13] Tiwari P, Kumar B, Kaur M, Kaur G and Kaur H (2011). Phytochemical screening and extraction: A review. International Journal of Pharmaceutical Sciences, 1: 98106. 
[14] Bahati LM, Mutwale PM, Ngombe NK, Moni B, Makengo GK, Mungitshi PM, Pambu A, Bongo G, Tujibikila AM, Kabeya JK, Mbadiko CM, Frederich M. and Mbemba FT (2017). Microscopic Features, Chromatographic Fingerprints and Antioxidant Property of Some Unconventional Green Leafy Vegetables Consumed in Bandundu, DR Congo. Pharmacognosy Communication, 7 (4): 158-163.

[15] Kapepula PM, Mungitshi PM, Franck T, Ngoyi DM, Kalenda PDT, Ngombe, NK Ngombe, Serteyn D, Tits M, Frédérich M, Tamfum JJ. (2017). Antioxidant potentiality of three herbal teas consumed in Bandundu rural areas of Congo Antioxidant potentiality of three herbal teas consumed in. Natural Product Research. 31 (16): 1940-1943.

[16] Adedapo AA, Jimoh FO, Koduru S, Afolayan AJ, Masika PJ. (2008). Antibacterial and antioxidant properties of the methanol extracts of the leaves and stems of Calpurnia aurea. BMC Complementary and Alternative Medicine. 8: 1-8.

[17] Bongo G, Inkoto C, Masengo C, Tshiama C, Lengbiye E, Djolu R, Kapepula M, Ngombe K, Mbemba T, Tshilanda D, Mpiana P, Ngbolua KN (2017). Antisickling, Antioxidant and Antibacterial Activities of Afromomum alboviolaceum (Ridley) K. Schum, Annona senegalensis Pers. and Mondia whitei (Hook. f.) Skeels. American Journal of Laboratory Medicine, 2 (4): 52-59.

[18] Sochor J, Ryvolova M, Krystofova O, Salas P, Hubalek J, Adam V, Trnkova L, Havel L, Beklova M, Zehnalek J, Provaznik I and Kizek R (2010). Automated Spectrometric Protocols for Determination of Antioxidant Activity: Advantages and Disadvantages. Journal of Molecules, (15): 8618-8640.

[19] Ananil K., Hudson J.B. de Souzal C., Akpaganal K., Towe G. H. N., AmasonJ. T. and Gbeassor. (2000) Investigation of medicinal plants of Togo for antiviral and antimicrobial activities. Phannaceutical Biology, 38 (1): 40-45.

[20] Ngbolua, K, Mubindukila, REN., Mpiana, PT, Tshibangu, DST, \& Ashande, M. C. (2014). Antibacterial and Antioxidant Activities of Anthocleista liebrechtsiana Wild \& T. Durand (Gentianaceae) Originated from Democratic Republic of the Congo. Journal of advancement in medical and life sciences, 2014c, 1 (1): 1-6.

[21] Mekonnen N., Makonnen E., Aklilu N., Amen G. (2012). Evaluation of berries of Phytolacca dodecandra for growth inhibition of Histoplasma capsulatum var. farciminosum and treatment of cases of epizootic lymphangitis in Ethiopia. Asian Pacific Journal of Tropical Biomedicine, 2 (7): 505-510.

[22] Kuete V, Ngameni B, Simo CCF, Tankeu RK, Ngadjui BT, Meyer JJM, Lall N, Kuiate JR. (2008). Antimicrobial activity of the crude extracts and compounds from Ficus chlamydocarpa and Ficuscordata (Moraceae). Journal of Ethnopharmacology, 120: 17-24.

[23] Kuete V. (2010) Potential of Cameroonian plants and derived products against microbial infections: a review. Planta Med, 76 (14): 1479-1491.
[24] Grassmann J (2005). Terpenoids as Plant Antioxidants. Vitamins and Hormones, 72 (5), 505-535.

[25] Matebie WA, Zhang W and Xie G (2019). Chemical composition and antimicrobial activity of essential oil from Phytolacca dodecandra collected in Ethiopia. Molecules, 24 (342): 1-8.

[26] Tura GT, Eshete WB and Tuchi GT (2017). Antibacterial efficacy of local plants and their contribution to public health in rural Ethiopia. Antimicrobial Resistance and Infection Control, 6: 76 doi: 10.1186/s13756-017-0236-6.

[27] Vithya ED, Maleeka BSF and Ravikumar K (2018). Evaluation of phytochemical and antimicrobial property of Phytolacca octandra. International Journal of Research in Ayurveda Pharmacy, 9 (6): 111-115.

[28] Bukatuka, F, Ngombe, K, Mutwale, K, Moni B, Makengo K, Pambu L, Bongo NG, Mbombo MP, Musuyu MD, Maloueki U, Koto-te-Nyiwa and Mbemba, F (2016). Bioactivity and Nutritional Values of Some Dioscorea Species Traditionally Used as Medicinal Foods in Bandundu, DR Congo. European Journal of Medicinal Plants, 14 (1), 1-11.

[29] Inkoto A. (2017). Etudes microscopique, photochimique et bio-activités de Aframomum aloboviolaceum, Annona senegalensis et Mondia whitei de la pharmacopée Congolaise. Mémoire de licence biologie. UNIKIN/RDC.

[30] Imene R. (2013). Etude in vitro de l'activité anti Leishmanienne de certaines plantes médicinales locales: cas de la famille deslamiacées. Thèse en vue d'obtention du diplôme : Magister en Biologie Appliquée. Université Constantine 1'Algerie.

[31] El Gharras, H. (2009). Polyphenols: Food sources, properties and applications - A review. International Journal of Food Science and Technology, 44 (12): 2512-2518.

[32] Perron, N. R., \& Brumaghim, J. L. (2009). A review of the antioxidant mechanisms of polyphenol compounds related to iron binding. Cell Biochemistry and Biophysics, 53 (2), 75 100.

[33] Vauzour, D., Vafeiadou, K., Rodriguez-Mateos, A., Rendeiro, C., \& Spencer, J. P. E. (2008). The neuroprotective potential of flavonoids: A multiplicity of effects. Genes and Nutrition, 3 (3-4), 115-126.

[34] Taye B, Giday M, Animut A and Seid J. (2011). Antibacterial activities of selected medicinal plants in traditional treatment of human wounds in Ethiopia. Asian Pacific Journal of Tropical Biomedicine, 1 (5): 370-375.

[35] Tadeg H., Mohammed E., Asres K., Gebre-Mariam T. (2005). Antimicrobial activities of some selected traditional Ethiopian medicinal plants used in the treatment of skin disorders. Journal of Ethnopharmacology, 100 (1-2): 168-175. 